\title{
C) Hitș TóRICA
}

\section{Entre a história e a literatura: E. P. Thompson e a crítica romântica da modernidade (I955-I993)}

\author{
Entre l'Histoire et la littérature: E. P. Thompson et la critique romantique de la \\ modernité (1955-1993)
}

\section{Edison Lucas Fabricio*}

Resumo: Este breve ensaio historiográfico é um esforço de interpretar o lugar do romantismo na obra de E. P. Thompson. Inicialmente, de forma bastante abreviada, é observada como a própria obra de Marx nasceu em um ambiente cultural marcado por tal sensibilidade. Em seguida, é buscado nos escritos de Michael Löwy e Robert Sayre o conceito de romantismo. A terceira e mais longa parte deste ensaio é dedicada à observação do lugar do romantismo na obra de E. P. Thompson. O trabalho parte do pressuposto que Thompson não apenas escreveu sobre essa forma de pensar, mas que absorveu vários elementos desta tradição de crítica à modernidade capitalista em sua maneira peculiar de escrever história.

Palavras-chave: Romantismo. Modernidade. Capitalismo.

Résumé: Ce petit essai est un effort pour interpréter le lieu du romantisme dans le travail de E. P. Thompson. Dans un premier temps, très brièvement, nous avons observé comment l'œuvre même de Marx est né dans une paysage culturel marqué par une telle sensibilité. Ensuite, on cherche dans les écrits de Michael Löwy et Robert Sayre le concept de romantisme. La troisième et la plus longue partie de cet essai est consacré à l'observation du romantisme dans le travail de Thompson. Ce essai suppose que non seulement Thompson a écrit à propos de cette façon de penser, mais qu'il a intégré plusieurs éléments de cette tradition critique de la modernité capitaliste dans sa façon particulière d'écrire l'histoire.

\footnotetext{
* Mestre e doutorando em História Cultural. Universidade Federal de Santa Catarina. Bolsista CAPES.
} 
Mots-clés: Romantisme. Modernité. Capitalisme.

\section{Palavras iniciais}

Vários autores mostraram que a obra de Karl Marx está mergulhada no contexto histórico-cultural “alemão" do século XIX e com ele guarda dívidas significativas. É importante apontar para o fato de que a obra de Marx começou a ser produzida num ambiente intelectual marcado pelo romantismo e, ao não operar cisões entre o jovem e o velho Marx, é possível perceber continuidades ou rastros do romantismo desde obras como o Manifesto do Partido Comunista até chegar n'O Capital. É salutar a citação de um dos trechos mais conhecidos do Manifesto para ilustrar como Marx e Engels empreendem uma crítica mordaz à modernidade burguesa e capitalista sob uma inconfundível inspiração romântica.

Onde quer a burguesia tenha chegado ao poder, ela destruiu todas as relações feudais, patriarcais, idílicas. Ela rompeu impiedosamente os variegados laços feudais que atavam o homem ao seu superior natural, não deixando nenhum outro laço entre os seres humanos senão o interesse nu e cru, senão o insensível "pagamento à vista". Ela afogou os arrepios sagrados do arroubo religioso, do entusiasmo cavalheiresco, da plangência do filisteísmo burguês, nas águas gélidas do cálculo egoísta. Ela dissolveu a dignidade pessoal em valor de troca, e no lugar das inúmeras liberdades atestadas em documento ou valorosamente conquistadas, colocou uma única inescrupulosa liberdade de comércio. A burguesia, em uma palavra, colocou no lugar da exploração ocultada por ilusões religiosas e políticas a exploração aberta, desavergonhada, direta, seca (MARX; ENGELS, 1998, p. Io).

Dessa forma, não é possível ignorar que o romantismo, que animou escritores como Goethe, Novalis, Fichte e Hegel, teve peso significativo também no pensamento de Marx. Um dos autores brasileiros a perceber essa relação foi Roberto Romano. Em Corpo e cristal: Marx e o romantismo, ele apresenta Marx como "um escritor que soube dançar com a pena”, portanto, dotado de criatividade ímpar, mas que, todavia, guardava uma profunda dívida "com a episteme de seu tempo". Ao mostrar as linhas de continuidade - numa crítica 
lateral a Althusser que nesta época falava em corte epistemológico -, Romano assinala que "contra essa desencantada prisão do maquinismo moderno, o juízo de Marx se estabelece solidamente no campo aberto pelos românticos e por Hegel" (ROMANO, 1980, p. 46). Nessas circunstâncias, as palavras de Marx teriam sido somadas aos protestos dos escritores românticos na ácida crítica à máquina capitalista.

Os românticos voltaram-se contra o sacrifício da individualidade nessa fábrica absurda, estranha às finalidades humanas. Marx, por sua vez, denunciou com virulência a destruição da individualidade por essa mesma máquina, mostrando, entretanto, que a finalidade de seu funcionamento era reproduzir um vampiro, um fantasma social que não tem existência própria, e cuja visibilidade é triplamente fugidia: seja sob a forma de moeda, seja sob a figura das máquinas, seja na fisionomia gasta do trabalhador. [...] O vampiro, capital que não é um ser, mas pura relação desprovida de sentimentos, apega-se ao corpo do operário, destruindo-lhe a alma pelo cálculo (Ibidem, p. 57).

Roberto Romano vê na obra de Marx, e especialmente n'O Capital, uma crítica mordaz ao sistema capitalista e ao maquinismo moderno, na esteira da visão de mundo romântica. Nessa pequena citação é possível identificar os grandes temas da crítica romântica ao capitalismo: o mecanicismo e a destruição da individualidade; a objetividade do lucro e a negação da subjetividade; o espírito de cálculo em detrimento do sentimento.

Para Romano, o romantismo em Marx funciona como uma lente ajustada na observação do capitalismo.

O romantismo em Marx opera como instrumento ótico, para melhor perceber os desgastes que a máquina, a serviço do capital, opera no ser humano, a ponto de transformar sua essência biológica, mesmo de reprodução vital, em triste atividade mecânica, força de trabalho (Ibidem, p. 6o).

Essas palavras iniciais sobre o romantismo em Marx servem de prelúdio ao exame das ressonâncias do romantismo na obra de E. P. Thompson. Não se quer propor que o marxismo seja romântico em sua essência, mas que seria um prejuízo interpretativo não levar em consideração a crítica romântica na formação da própria obra marxiana e na 
posterior tradição marxista, especialmente na obra de E. P. Thompson, colocada em relevo neste texto.

$\mathrm{O}$ ano de 2013 celebrou cinquenta anos do clássico $A$ formação da classe operária e completou a segunda década da morte de seu autor, Edward Palmer Thompson; sem dúvida um dos intelectuais de maior prestígio entre os historiadores marxistas da Inglaterra. Em todo o mundo acadêmico, e nas mais variadas revistas especializadas, a obra de E. P. Thompson foi lembrada e celebrada, seja por seu vigor teórico ou mesmo por sua capacidade de inspirar os historiadores. A ressignificação de termos como classe e cultura, a discussão em torno da economia moral e da força do direito baseado nos costumes, ou mesmo temas como democracia e exterminismo, tão presentes no debate da Guerra Fria, tornaram Thompson um autor incontornável na historiografia da segunda metade do século XX. No entanto, embora continuamente revisitado, um aspecto da obra de Thompson tem sido preterido, ou ao menos recebido pouca atenção: a sua relação com o romantismo, enquanto uma sensibilidade e enquanto uma tradição literária na Inglaterra. Este texto pretende ser uma contribuição para esse debate.

Neste intróito é necessário também assinalar a compreensão que se pretende atingir com a noção de ressonância. Formulada por Stephen Greenblatt para a compreensão de textos e os mais variados objetos culturais, na esteira de um novo historicismo, esta noção vai além da ideia de influência, pois tem o poder de "alcançar um mundo maior além de seus limites formais, de evocar em quem os vê as forças culturais complexas e dinâmicas das quais emergiu”. Desta forma, como assinala Greenblat, a ressonância guarda certo parentesco com a nostalgia, é "um híbrido forjado nas brechas pouco conhecidas, nas cesuras". Daí o autor precisar que o que se busca são as condições de produção de uma determinada obra, neste caso historiográfica, "não como um pano de fundo estável e préfabricado contra o qual se projetam os textos [...], uma rocha para nela amarrar com segurança a interpretação", mas indícios para situar uma obra em relação a outras obras e suas temporalidades, "simultaneamente a historicidade dos textos e a textualidade da história” (GREENBLATT, I99I, p. 250-255).

\section{Para uma definição do romantismo}

Há algum tempo Michael Löwy e Robert Sayre, no caminho aberto por Lucien Goldman, vem insistindo na necessidade de uma sociologia da cultura mais ampla. Principalmente em livros como Romantismo e política e Revolta e melancolia: o romantismo na contramão da modernidade (publicados, respectivamente, no Brasil em I993 e I995), os autores 
insistem numa reavaliação do movimento romântico, especialmente em seu caráter polimorfo e multidimensional. Para caracterizar o romantismo, os autores se apropriam da noção de "visão de mundo" ou "estrutura mental coletiva", de Lucien Goldmann, donde é possível pensar o romantismo para além da literatura e da arte, englobando disciplinas como a filosofia, a história, a sociologia, o pensamento político, jurídico, econômico e teológico. ${ }^{\mathrm{I}}$

Para Löwy e Sayre, o romantismo é incompreensível sem a consideração da modernidade capitalista e o industrialismo dela decorrente. É como reação à modernidade capitalista, fria, calculista e mecânica que emerge a crítica romântica. Assim, como "autocrítica da modernidade", a visão de mundo romântica é "por essência anticapitalista" (LÖWY; SAYRE, 1995, p. 30). Os autores assinalam que essa noção de "romantismo anticapitalista" não é recente na literatura marxista, já que ela teria aparecido pela primeira vez em 193I, num ensaio de G. Lukács sobre Dostoievsky. No entanto, Lukács teria visto no romantismo uma tendência à direita e ao fascismo, o que permite aproximá-lo da perspectiva aberta por Roberto Romano, que coloca o romantismo na origem do totalitarismo (LÖWY; SAYRE, I993, p. 75). ${ }^{2}$

Para Robert Sayre e Michael Löwy, a análise do romantismo é um desafio, sobretudo por seu caráter contraditório, que é ao mesmo tempo "revolucionário e contrarevolucionário, individualista e comunitário, cosmopolita e nacionalista, realista e fantástico, retrógrado e utopista, revoltado e melancólico, democrático e aristocrático, ativista e contemplativo, republicano e monarquista [...]" (LÖWY; SAYRE, I995, p. 9). Para dar conta da amplitude e do desafio de analisar o romantismo, Löwy e Sayre criaram uma tipologia das configurações assumidas pelo romantismo. Para os autores há ao menos seis de tipos de romantismo: restitucionista, conservador, fascista, resignado, reformador e revolucionário e/ou utópico, sendo que o romantismo revolucionário pode ter diferentes tendências (jacobino-democrática, populista, socialista utópico-humanista, libertária, marxista).

Para além de toda essa diversidade de manifestações do romantismo, é possível eleger alguns aspectos essenciais que lhe conferem unidade e identidade. A característica elementar que alimenta a crítica romântica é o sentimento de perda; ou seja, na modernidade capitalista alguns valores teriam sidos alienados da sensibilidade humana.

\footnotetext{
I A noção de "visão de mundo" enunciada por Goldmann procura ir além do conceito de ideologia, que no fundo guarda uma relação com a categoria classe social. Portanto, a noção de "visão de mundo" diria respeito a um conjunto de representações e valores coletivos, estando mais próxima da noção de mentalidades produzida no âmbito da Escola de Annales, mas dela também se afastaria na medida em que define a existência de visões de mundo antagônicas e não totalizantes.
} 
Tal alienação teria produzido uma crise de orientação, um sentimento de viver exilado no próprio presente. Assim, não é fortuito que a crítica romântica seja nutrida pela nostalgia, melancolia e revolta pela perda de um passado pré-capitalista. No entanto, o romantismo não é apenas passadista, pois ele pode tomar as características e valores de um passado, muitas vezes idealizado, e transformá-los em utopia, em projetos a serem perseguidos. ${ }^{3}$ Para além do sentimento de perda, Löwy e Sayre elegem outros cinco aspectos que seriam alvos da crítica romântica: o desencantamento do mundo, a mecanização do mundo, a quantificação do mundo, a abstração racionalista e a dissolução dos vínculos sociais.

A partir desse aporte fornecido pela leitura de Löwy e Sayre, nas próximas páginas se poderá ver como a crítica romântica da modernidade capitalista aparece nas obras de E. P. Thompson. Parte-se do pressuposto que Thompson não apenas nutriu interesse pela história dos poetas românticos, mas que sua própria escrita e visão de mundo são marcadas pelo modo romântico de apreensão da realidade.

\section{Afinidades eletivas: E. P. Thompson e o romantismo ${ }^{4}$}

Para melhor compreender a obra de E. P. Thompson é imprescindível o conhecimento de sua própria trajetória pessoal e política. Thompson nasceu em 1924, na Inglaterra, e faleceu em 1993. No início da década de I940 ingressou no Partido Comunista e logo seguiu para o campo de batalha da II Guerra Mundial. A morte do irmão na guerra teria marcado fortemente Thompson e, especialmente, sua visão sobre o fascismo. Ao voltar da guerra graduou-se em História e iniciou sua carreira docente nas aulas noturnas para adultos (MÜLLER; MUNHOZ, 20IO).

Ainda no que diz respeito ao peso da influência familiar na formação de Thompson, é importante salientar que sua infância transcorreu em Oxford, onde o pai, E. John Thompson, era poeta e professor de cultura e língua bengali. Segundo Gonzáles, a família de Thompson vinha de uma longa tradição metodista e liberal. Os pais tinham sido missionários na Índia. Ao longo dos anos 1920, E. John Thompson foi progressivamente se posicionando contra o imperialismo inglês na Índia e a favor da independência, inclusive alimentada por relações com Nehru e Gandhi. Embora Thompson rejeitasse o papel da educação metodista, e da religião em geral, na sua formação, vários autores têm enfatizado

\footnotetext{
${ }^{2}$ Sobre a perspectiva de Roberto Romano ver (ROMANO, 1997).

${ }^{3}$ Sobre a relação entre romantismo e utopia ver (SALIBA, I99I).

${ }^{4}$ A relação de Thompson com o romantismo foi tangencialmente analisada por Löwy e Sayre em sugestivo artigo A corrente romântica nas ciências Sociais da Inglaterra: Edward P. Thompson e Raymond Willians, mas com um reduzido espectro de obras. Ver (LÖWY; SAYRE, I999).
} 
as "virtudes puritanas" de grande parte dos intelectuais comunistas britânicos, principalmente na geração do Grupo de Historiadores do Partido Comunista (GHPC), na qual há evidente identificação com o "sentido de la autodisciplina, abnegación, espíritu de entrega o vocación transformadora del mundo" (GONZALEZ, 2007, p. 64). Especificamente no âmbito da educação familiar, a influência do pai foi decisiva em Thompson. Segundo Bryan Palmer, "no es difícil apreciar las sensibilidades y el estilo del padre, así como sus cimientos, en el internacionalismo y en la imaginación, en la política posterior de Thompson, en sus polémicas y en su prosa histórica" (PALMER, 2004, p. 45).

Estes traços biográficos ajudam a entender as escolhas intelectuais e políticas de Thompson. Ao ingressar em Cambridge, Thompson dirigiu-se para a disciplina de História, e não é fortuito que tenha iniciado e abandonado o curso de Literatura, na época, anos 1930 e início da década de 1940, a disciplina dominante nos estudos de Letras. Foi no ambiente de Cambridge que Thompson entrou em contato com círculos de esquerda da universidade, onde conheceu sua companheira, Dorothy, e os estudantes que se tornariam membros do Grupo de Historiadores do Partido Comunista.

Foi nesse contexto, em 1955, que apareceu a primeira obra de E. P. Thompson, William Morris: de romântico a revolucionário, que marcou de forma indelével sua relação com o romantismo.

El encuentro de Thompson con Morris resultó decisivo en su trayectoria política e intelectual. Con el estudio de la obra y vida de Morris, Thompson no sólo terminó por decantarse por la profesión historiográfica, sino que adquirió un arsenal teórico - y añadiríamos afectivo - bien avenido con el capital cultural que hasta entonces había acumulado, fundamentalmente a través del seno familiar y del contacto con los círculos izquierdistas universitarios. Desde ese momento, la particular combinación que ensaya el historiador inglés entre la tradición de Marx y la de Morris, contribuye a explicar en buena medida las tomas de posición intelectuales y políticas que llevará a cabo en años posteriores; momento en el que la tradición historiográfica ha reconocido, produce sus obras más reputadas. (GONZALEZ, 2007, p. 60). 
No prefácio à edição espanhola de $1988,{ }^{5}$ Thompson assinalava que nos últimos trinta anos havia percebido a importância de Willians Morris para seu próprio tempo. Segundo Thompson, "Morris pertenece a un tiempo en el que la tradición socialista europea poseía un fuerte vigor imaginativo y no se arredraba ante la especulación utópica”. Assim, a reabilitação de Morris também era importante para a própria tradição marxista, tanto pelos pontos que o ligavam a ela, como pelos quais o faziam um divergente, sendo um deles a "su desconfianza hacia el culto acrítico al crecimiento de la producción mecanizada [...] Morris fue un comunista 'verde'. Pero fue también un crítico del estatismo centralizado" (THOMPSON, 1988, p. 7).

$\mathrm{Na}$ primeira parte do livro, Thompson descreveu a figura de Morris em um ambiente intelectual ainda marcado pelas perdas de Byron, Shelley e Keats. Nascido em I843, Morris viveu sua adolescência sob "grandes remolinos de aquella perturbación del espíritu humano de la que estos poetas habían sido portavoces: la revuelta romántica" (Ibidem, p. II). Segundo Thompson, a poesia de The defense of Guenevere and other poems, de I858, traria ainda os resquícios apaixonados dessa revolta romântica. Esse livro teria sido a "primeira justa" de Morris no combate ao vitorianismo.

Segundo Löwy e Sayre, o romantismo, buscando reverter o sentimento de perda no presente, vai buscar no passado o sublime, a beleza e a pureza. Não raro, os românticos buscaram na Idade Média, muitas vezes idealizada, um refúgio à dura realidade da modernidade capitalista. O caso de Willians Morris pode ser pensado nessa perspectiva, pois "la vida de la Inglaterra victoriana era intolerable y no podía ser soportada por seres humanos. Los valores del capitalismo industrial eran perniciosos y despreciables; eran un escarnio del pasado de la humanidad". Dessa forma, o retorno intelectual de Morris à Idade Média era uma forma de reencontrar "una comunidad real de seres humanos, una sociedad orgánica precapitalista con valores y un arte proprio, en agudo contraste con los de la Inglaterra vitoriana" (Ibidem, p. I2, I3).

O título do primeiro capítulo, Sir Lancelot e Mr. Gradgrind, dá o tom da discussão proposta por Thompson sobre os primeiros escritos de Morris. Para Thompson, Lancelot,

\footnotetext{
${ }^{5}$ Essa obra de Thompson teve duas edições em inglês; a primeira, de 1955, com mais de 900 páginas, e a segunda, de 1977, onde houve um corte, pelo próprio autor, de cerca de Ioo páginas. A justificativa de Thompson era de que já não fazia sentido manter o teor anti-stalinista da primeira edição. Segundo Gonzáles, é consenso entre os especialistas na obra de Thompson "la influencia que ejerce la figura de Morris sobre el programa intelectual y político del historiador inglés, fundamentalmente a partir de su ruptura con el PCGB, un año después de la primera edición de la obra" (GONZALEZ, 2007, p. 62). Nos apêndices da obra também constam importantes documentos, como o "Manifesto da Liga Socialista", escrito por Morris, e o "Postscriptum de 1976", onde Thompson realiza um balanço da recepção de sua obra sobre Morris. O "Postscriptum de 1976" também ganhou uma tradução para o português no livro "E. P. Thompson: política e paixão”, organizado pelos professores Ricardo Müller e Adriano Duarte. Ver (MÜLLER; DUARTE, 2OI2).
} 
típico herói medieval, alimentado pelo ideal cavalheiresco de honra e nobreza de espírito, era a antítese de Mr. Gradgrind, personagem de Charles Dickens em Tempos difíceis (I854), arquétipo do individualismo burguês da era vitoriana. Nas palavras de Thompson,

\begin{abstract}
Gradgrind no tiene solamente poder y dinero: además posee una teoría para justificar y perpetuar la explotación. La burguesía vitoriana había construido, a base de fragmentos de Adam Smith y Ricardo, de Bentham y Malthus, un sistema teórico con la solidez del acero forjado, y ahora lo estaban imponiendo con el auxilio de la autoridad del Estado y de la Ley, y santificándolo con las bendiciones de la Religión. Las leyes de la oferta y la demanda eran "leyes de Dios" y en todos los demás asuntos sociales importantes cualquier otra consideración debía someterse a los valores del mercado (Ibidem, p. I8).
\end{abstract}

A crítica do capitalismo realizada por Thompson a partir de William Morris arremata em poucas linhas um contexto de contradições profundas. Não por acaso, Morris encontrou na Idade Média o lugar distanciado da crítica à modernidade. O medievalismo de Morris foi alimentado desde a tenra infância: suas leituras novelescas teriam começado aos sete anos. No entanto, como apontava Thompson, tal medievalismo era um recurso didático e epistemológico (não é fortuito que Thompson faça o mesmo exercício em suas obras e, ao historicizar o século XVIII, tenha vislumbres perspicazes e agudos sobre o próprio século XX). Morris inclusive rejeitava o exagero passadista de muitos de seus pares românticos do período. Para ele, o recurso ao passado medieval era uma forma de afastamento da sociedade burguesa, uma maneira de espreitá-la com maior acuidade.

El medievalismo fue una de las formas características que adoptó el florecimiento tardío del movimiento romántico en la Inglaterra de mediados del siglo XIX. Fue, en su impulso esencial, una revuelta contra el mundo de la Era del Ferrocarril - y los valores de Gradgrind. Situaba en el pasado la existencia de una forma de sociedad cuyos valores eran más exquisitos y más ricos que los del beneficio y la utilidad propios del capitalismo (THOMPSON, 1988, p. 19).

Nos escritos de juventude, produzidos ainda no chamado outono do romantismo inglês, os grandes mestres de Morris teriam sido Keats, Thomas Carlyle e John Ruskin. A literatura, portanto, ocupou um espaço significativo na vida Morris, e em alguns momentos 
ele deu a entender que essa era a única forma de militância política. Segundo Thompson, em uma carta de I885, escrita a um jovem socialista, Morris teria assinalado as vantagens de ter nascido mais tarde, quando eram possíveis outras formas de intervenção política, muito diferentes de seu tempo, "una época sombría, tan terriblemente dominada por el aburguesamiento y el filisteísmo, que nos vimos forzados a concentrarnos en nosotros mismos; sólo había alguna esperanza en el mundo del arte y la literatura" (Ibidem, p. 23).

$\mathrm{Na}$ segunda parte do livro sobre Morris, Thompson se deteve nos próximos vinte anos posteriores à publicação de The Defense of Guenevere. Esses teriam sido os anos conflituosos de sua poesia, mas também anos de esperança e coragem, e, sobretudo, nos quais Morris se consagraria nas artes decorativas, quando se dedicou à Red House e à Firma, instituições dedicadas às artes e a "reformar 'todo eso', reformar una época farisaica por medio de las artes decorativas" (Ibidem, p. 97).

A terceira e mais longa parte da biografia de Morris é dedica ao socialismo. A relação de Morris com o socialismo teria iniciado no princípio da década de 1880 , um momento muito particular em que a Inglaterra tinha se tornado a "fábrica do mundo". Para Thompson a tradição socialista praticamente não existia na Grã-Bretanha antes de I870, exceto pela existência de alguns militantes owenistas (THOMPSON, I988, p. 289). Ademais, é nessa parte que Thompson discutiu as várias divisões do movimento socialista na Inglaterra e a adesão de Morris aos princípios da obra de Marx-Engels. Foi neste período também que Morris esteve mais próximo de Engels e de Eleanor Marx, a filha mais jovem de Karl Marx, junto à Liga Socialista. Morris dirigiu por um longo tempo o periódico The Commonweal, onde membros da Liga, como Bernard Shaw, Paul Lafargue e outros, infringiam duras críticas ao imperialismo britânico. Nesse periódico também levantou com vigor a bandeira da liberdade de expressão. A Liga Socialista, principalmente a partir de I887, passou a entrar em contato com as massas trabalhadoras e dar suporte aos seus protestos, greves e movimentos. Em I896, aos 62 anos, depois de muitas disputas no interior da Liga, Morris faleceu. Um dos médicos que atestou sua morte teria dito que Morris "había muerto de su entusiasmo por propagar los principios del socialismo". Outro médico teria dado outro diagnóstico: "la enfermedad es simplemente ser William Morris y haber trabajado más que diez hombres juntos" (Ibidem, p. 584).

Na última parte da biografia, Thompson se dedicou a captar as intuições teóricas a partir de suas obras sobre Morris, desde seu afastamento de algumas proposições de Ruskin e Carlyle até seu diálogo com a obra de Marx. Thompson passa por temas como o significado do trabalho, o desenvolvimento técnico das máquinas e o que isso poderia significar na vida dos trabalhadores sob o socialismo; além do valor da arte para os 
trabalhadores e vários outros assuntos. Nessa seção Thompson também analisou os diversos livros de Morris, dando ênfase especial a News from Nowhere, livro que descreve uma sociedade socialista utópica. Segundo Thompson, "en Noticias de ninguna parte Morris no permite que olvidemos nunca durante mucho tiempo este sentimiento de tensión entre lo real y lo ideal. [...] No deja de ser una utopía, que sólo un escritor nutrido en la tradición romántica podría haber concebido" (Ibidem, p. 638, 639).

Ao que Thompson acrescentou:

\begin{abstract}
$\mathrm{Al}$ mismo tempo, esto pone de relieve el hecho de que noticias de ninguna parte no tiene por qué ser, ni nunca pretendió ser, un retrato literal de una sociedad comunista. La mitad de su intención es la crítica de la sociedad capitalista, la otra mitad, una revelación de las capacidades latentes en hombres y mujeres, cuya expresión concreta la sociedad de clases deniega o distorsiona (Idem).
\end{abstract}

Mas qual a origem da grandeza de Morris? Para Thompson, ela certamente não residiria na cultura inglesa, por mais que tenha mostrado o quanto Morris devia à tradição romântica de seu país. Para Thompson, o que o fascinava em Morris era a "cualidad que une e informa todo aspecto de su vida y de su trabajo. A esta cualidad no encontramos modo más idóneo de llamarla que 'realismo moral': es el ejemplo moral práctico de su vida lo que produce admiración [...]" (THOMPSON, I988, p. 659).

Para Thompson, foi o realismo moral de Morris que o colocou numa posição de destaque na tradição intelectual britânica. O compromisso político e intelectual de Morris não apenas o tornou um dos socialistas mais célebres da Inglaterra, mas, sobretudo, criou um modelo de intervenção política: o intelectual engajado junto aos trabalhadores.

William Morris fue el primer creador de envergadura, en el mundo, que tomó posiciones, conscientemente y sin sombra de compromiso, junto a la clase obrera revolucionaria; el primero en participar en el trabajo cotidiano de construir el movimiento socialista; el primero en poner su inteligencia y su genio a disposición de dicho movimiento en su lucha. [...] Morris ocupará siempre un lugar de importancia única en la tradición revolucionaria británica. Noticias de ninguna parte ha cruzado muchas fronteras y la importancia de su realismo utópico adquiere un creciente reconocimiento internacional. Pero la fuerza de Morris, no menos que la de Gramsci, se apoya profundamente en las fuerzas de una tradición más 
local. La crítica romántica del capitalismo industrial, la obra de Ruskin y Carlyle, asumen un nuevo significado a la luz de la transformación de la tradición llevada a cabo por Morris (Ibidem, p. 668, 669).

O solo inglês, o caráter local da atuação de Morris, é comparado à militância intelectual e política de Gramsci. Essa ênfase de Thompson no caráter nacional do socialismo de Morris não é fortuita, já que em grande parte de sua obra sempre procurou dar destaque à "peculiaridade dos ingleses". Obviamente, isso lhe custou várias críticas, entre elas a de ser "insular demais", ou ainda, um "populista provinciano" (PALMER, 2004, p. 29).

O ensaio As peculiaridades dos ingleses, de 1965, publicado na coletânea A miséria da teoria, é um exemplo do apego de Thompson às tradições libertárias na Inglaterra. Esse ensaio surgiu a partir de sua saída da New Left Review, quando a direção da revista foi passada a Perry Anderson e a Tom Nairn. Estes autores teriam avaliado a cultura política inglesa como dominada por um "míope empirismo" e marcada pelo "isolamento e provincianismo", donde havia resultado apenas "atraso e tradicionalismo", "religiosidade e aura moralista”, e "desconfiança instintiva da razão" (THOMPSON, I998, p. 77). A essa visão, Thompson divergiu frontalmente, aludindo principalmente a William Morris:

\footnotetext{
Quando Willians Morris juntou a crítica romântica à marxista e escreveu sobre a "baixeza moral inata" do sistema capitalista, não descreveu uma superestrutura moral derivada de uma base econômica. Ele quis dizer - e demonstrou amplamente seu significado - que a sociedade capitalista estava fundada sobre formas de exploração simultaneamente econômicas, morais e culturais (Ibidem, p. I66, grifo do autor).
}

Neste pequeno extrato é possível perceber a apologia de Thompson à contribuição do romantismo para o pensamento marxista. A defesa da "ilha empírica" de Thompson não era apenas um exercício de retórica provinciana, mas a forma de advogar a peculiaridade da cultura política inglesa, que não deveria ser interpretada à sombra da história de outros países. Esse é o motivo que o levou a mostrar que no país onde floresceu o capitalismo, também emergiram diversas formas de resistência política e intelectual que não deviam ser ignoradas.

O diálogo com a tradição romântica também deixou rastros marcantes na segunda obra de Thompson, publicada oito anos após o livro sobre Morris, que também o tornou 
um dos mais célebres historiadores marxistas do século $\mathrm{XX}$, The making of the english working class, traduzida no Brasil como A formação da classe operária inglesa. O objetivo de Thompson nesse livro era estudar a classe trabalhadora enquanto acontecimento e relação. Para o autor, era a relação entre pessoas e contextos históricos determinados que produzia a experiência, e esta a consciência de classe. Assim, a classe surgia como resultado de experiências comuns, herdadas ou partilhadas, articuladas numa identidade. $\mathrm{O}$ entendimento de Thompson era o de que não se podia compreender suficientemente a história da classe trabalhadora a menos que se visse nela uma "formação social e cultural" (THOMPSON, 2004, p. I2).

A partir dessa premissa, Thompson enunciava, com inconfundíveis traços românticos, seu empreendimento historiográfico.

Estou tentando resgatar o pobre tecelão de malhas, o meeiro luddita, o tecelão do "obsoleto" tear manual, o artesão "utópico". [...] Seus ofícios e tradições podiam estar desaparecendo. Sua hostilidade frente ao novo industrialismo podia ser retrógada, seus ideais comunitários podiam ser fantasiosos. Suas conspirações insurrecionais podiam ser temerárias. Mas eles viveram nesses tempos de aguda perturbação social, e nós não. Suas aspirações eram válidas nos termos de sua própria experiência [...] (Ibidem, p. I3).

No excerto acima, Thompson retomou elementos importantes da retórica romântica, como o sentimento de perda das tradições populares, dos laços comunitários e dos ofícios que, naquele momento, eram reordenados segundo a nova divisão do trabalho. O industrialismo, com sua pregação do incessante aprimoramento técnico do maquinário, havia suplantado o “tecelão do 'obsoleto' tear manual”. Mas Thompson, assim como Morris, não era um romântico passadista que se sentia resignado diante do turbilhão da modernidade capitalista. Era preciso ser utópico, tanto no sentido de Notícias de lugar nenhum, como na percepção de que aquele contexto tinha se tornado carente de imaginação utópica. Por isso, o retorno intelectual ao passado não era mero exercício diletante, mas convertia-se numa ferramenta didática e política.

Podemos descobrir, em algumas das causas perdidas da Revolução Industrial, percepções de males sociais que ainda estão por curar. Além disso, a maior parte do mundo ainda hoje passa por problemas de 
industrialização e de formação de instituições democráticas, sob muitos aspectos semelhantes à nossa própria experiência durante a Revolução Industrial. Causas que foram perdidas na Inglaterra poderiam ser ganhas na Ásia ou na África (THOMPSON, 2004, p. I3).

Dorothy Thompson observa que E. P. Thompson, a cada dez anos, publicava uma obra importante, que trazia contribuições relevantes ao campo historiográfico britânico. Já se mencionou aqui o livro sobre Morris, da década de 1950, bem como o livro sobre a classe operária inglesa, da década de 1960. Na década de 1970 veio ao público o livro Whigs and hunters, traduzido como Senhores e caçadores, um importante estudo sobre a história da Lei Negra de I723 (THOMPSON, 2002, p. 7-9).

Por sua vez, Senhores e caçadores veio ao público em 1975. Thompson explicou que esse livro era um experimento historiográfico. O propósito era entender como uma única lei, em I723, criava cinquenta novos delitos capitais. Portanto, nas três partes do livro, Thompson partiu das margens, as florestas de Windsor, Hampshire, Enfiel e Richmond, até chegar à corte inglesa. Esse exercício metodológico é consoante com a prática historiográfica consagrada por Thompson como "a partir de baixo". Nas palavras de Thompson:

[...] parti da experiência de humildes moradores das florestas e segui, através de evidências contemporâneas superficiais, as linhas que ligavamnos ao poder, em certo sentido as próprias fontes me obrigaram a encarar a sociedade inglesa em 1723 tal como elas mesmas a encaram, a partir de "baixo" (THOMPSON, 1997, p. 17).

A chamada Lei Negra, decretada em I723, era uma medida jurídica e política para conter as várias ações dos "negros", pessoas armadas com espadas ou armas de fogo que pintavam o rosto com fuligem para não serem reconhecidas no momento em que praticavam delitos, como a caça a gamos, cervos e coelhos. Paulatinamente, a lei foi ampliada para abarcar delitos como a pesca em propriedades particulares ou reais, a derrubada de árvores e o envio de cartas anônimas. Desde o início do texto, Thompson deixou claro que o Estado Britânico existia para "preservar a propriedade e, incidentalmente, as vidas e liberdades dos proprietários" (Ibidem, p. 2I).

Em meio ao progressivo cercamento das terras comunais e a proibição da caça, os camponeses se organizaram para resistir. Um dos grupos de caçadores clandestinos chegou 
a criar uma espécie de irmandade e eleger um líder, que ficou conhecido como Rei John. Thompson explica que, em I72I,

[...] por alguns meses, o Robin Hood da lenda encarnou-se no "Rei John". Os ressentimentos de décadas protegiam ele e seu bando, quando cavalgava abertamente para administrar a justiça popular. Seus adeptos pareciam capazes de desaparecer nos recôncavos do ocultamento com a mesma facilidade de um vietcongue (THOMPSON, 1997, p. 182).

Neste contexto, das duas décadas iniciais do século XVIII, ainda não é possível falar em uma crítica romântica do industrialismo, ou em uma desumanização das relações sociais sob o regime fabril. Todavia, e Thompson percebeu com maestria este processo, o regime de propriedade havia sido alterado profundamente e as relações sociais não deixaram de ser afetadas. Foi no novo regime de propriedade que se manifestou o espírito do cálculo ou da quantificação característico da modernidade capitalista. Esse é o contexto em que ocorre "a quantificação mercantilista, o envenenamento da vida social pelo dinheiro" (LÖWY; SAYRE, I995, p. 59).

A Lei Negra só podia ter sido formulada e decretada por homens que tinham formado hábitos de distância mental e frivolidade moral em relação à vida humana - ou, mais especificamente, em relação às vidas do "tipo de gente desregrada e desordeira”. Precisamos explicar não só uma emergência, mas uma emergência que agia sobre a sensibilidade desses homens, para quem a propriedade e o status privilegiado dos proprietários vinham assumindo, a cada ano, um maior peso nas escalas de justiça, até a própria justiça não passava, aos seus olhos, das fortificações e defesas da propriedade e seu concomitante status. Sob alguns aspectos, o século I8 demonstrou uma tolerância: homens e mulheres não eram mais mortos ou torturados por suas opiniões ou crenças religiosas, como feiticeiros ou heréticos; políticos destituídos não subiam ao cadafalso. Mas, a cada decênio, definiam-se mais e mais invasões da propriedade como delitos capitais (THOMPSON, 1997, p. 254).

Para Thompson, o significado da Lei Negra para a história do capitalismo na Inglaterra residia na paulatina abolição do "direito costumeiro não-codificado" e no "longo declínio do controle e disciplina de classe”. Assim, às vésperas da Revolução Industrial, 
"em vez do poste de açoitamento e do trono de tortura [...] contra os vagabundos, os economistas defendiam a disciplina dos salários baixos e da fome, e os advogados a pena de morte" (Ibidem, p. 282).

Segundo Dorothy Thompson, E. P. Thompson, além dos livros acima citados, gostaria de ter se dedicado a dois outros projetos. Thompson tinha interesse em escrever sobre dois assuntos: o primeiro, sobre a cultura popular consuetudinária inglesa do século XVIII; o segundo trataria do movimento romântico inglês da década de I79o. Ao sentir que não seria possível, ele reuniu os diversos ensaios sobre o primeiro assunto e os editou em I99I, sob o título de Costumes em comum - estudos sobre a cultura popular tradicional (THOMPSON, 2002, p. 7-9).

Nos diversos artigos de Costumes em comum, Thompson se dedicou a estudar a cultura plebeia na Inglaterra. $\mathrm{O}$ autor compartilhava a ideia de que o século XVIII marcou o declínio dos costumes, principalmente daqueles que reivindicavam direitos. Esse também teria sido o momento do declínio da magia, da feitiçaria e da cultura popular em geral. Thompson explicava que "o povo estava sujeito a pressões para 'reformar' sua cultura segundo as normas vindas de cima, a alfabetização suplantava a transmissão oral, e o esclarecimento escorria dos estratos superiores aos inferiores - pelos menos, era o que se supunha". No entanto, as pressões por reforma dos costumes encontraram a "resistência teimosa" da plebe e acabou por criar um hiato entre a cultura plebeia e a patrícia; donde surgiu o folclore, uma iniciativa não desprovida de condescendência para com os "rudes" costumes dos de baixo. Os costumes no século XVIII guardavam muitas afinidades com o direito consuetudinário e, muitas vezes, tinham a força legal da lei estatutária, pois incorporavam as regras precedentes já aceitas por determinada comunidade. "O costume constituía a retórica de legitimação de quase todo o uso, prática ou direito reclamado" (THOMPSON, 2008, p. I3).

Thompson argumentava que a história inglesa do século XVIII era marcada pelo confronto entre uma economia de mercado, cuja figura emblemática era Adam Smith, e uma economia moral costumeira, formulada pela plebe. $\mathrm{O}$ autor não via nesse confronto um retrocesso em relação às forças modernizadoras, mas uma resistência em nome do costume e contra o agravamento da exploração plebeia. Daí a importância de estudar o confronto e a destruição dos modos de vida pré-modernos. $\mathrm{Na}$ sua visão, a plebe era produtora de uma cultura tradicional rebelde,

[...] que resiste, em nome do costume, às racionalizações e inovações da economia (tais como cercamentos, a disciplina de trabalho, os livres 
mercados não regulamentados de cereais) que os governantes, os comerciantes ou empregadores querem impor [...] A inovação do processo capitalista, é quase sempre experimentada como uma exploração, a expropriação de direitos de uso costumeiro, ou a destruição violenta de padrões valorizados de trabalho e lazer (Ibidem, p. 19).

Dessa forma, torna-se compreensível o interesse de Thompson pelos motins de fome, como resistência ao mercado e em nome da economia moral, ou mesmo a atenção dada ao tempo no cotidiano pré-industrial. Para Thompson, houve uma abolição da concepção de tempo baseado nos ciclos naturais e implantou-se uma nova mentalidade de tempo (calculado, dividido, medido, racionalizado e comercializado). O industrialismo havia desorganizado todo um mundo pautado segundo as tradições. A sociedade industrial oriunda do capitalismo erigiu o trabalho como a atividade social mais importante e transformou, profundamente, as tradições e os costumes.

A revolução industrial e a concomitante revolução demográfica foram o pano de fundo da maior transformação da história, ao revolucionar as "necessidades" e destruir a autoridade das expectativas baseadas nos costumes. É isso sobretudo o que estabelece a distinção entre o "préindustrial" ou "tradicional" e o mundo moderno. As gerações sucessivas já não se colocam em posição de aprendizes umas das outras (THOMPSON, 2008, p. 23).

No excerto acima, Thompson retomou outro tema caro à tradição romântica: a dissolução dos vínculos sociais. Para os românticos, uma das consequências da emergência do capitalismo é a proscrição das relações comunitárias, dos vínculos orgânicos entre os seres humanos, a comunidade e a natureza. O indivíduo isolado em seu egoísmo tornava-se a marca do éthos capitalista. Portanto, esse "diálogo de surdos” percebido no capitalismo, onde as sucessivas gerações não mais comunicam, produz uma sociedade que eleva continuamente suas expectativas materiais, e que ao não

[...] definir suas necessidades e satisfações materiais de mercado despejando todos os recursos da Terra no mercado - pode ameaçar a própria espécie (no Sul como no Norte) com uma catástrofe ecológica. O responsável por essa catástrofe será o homem econômico, seja na sua 
forma clássica do capitalismo ávaro, seja na forma do homem econômico rebelde da tradição marxista ortodoxa (Idem).

Na visão de Edgar De Decca, é possível identificar na história da classe operária de Thompson a partilha do sonho de uma sociedade de "consciência costumeira", em que a perseguição da felicidade não é sinônimo de acúmulo. Obviamente Thompson, apesar de sua predileção, reconheceu a enorme carência cultural e a pobreza dessas sociedades précapitalistas (DE DECCA, 2002, p. 65). Para Thompson, "nunca retornaremos à natureza humana pré-capitalista, mas lembrar como eram seus códigos, expectativas e necessidades alternativas pode renovar nossa sensibilidade da gama de possibilidades implícitas no ser humano" (THOMPSON, 2008, p. 23). Portanto, não se tratava de uma nostalgia, mas de reencontrar no passado os germes da resistência no presente. Nesse sentido, Thompson não economizou críticas ao capitalismo, mas também não absolveu o socialismo de Estado. Assim, questionava-se: era possível

[...] nos preparar para uma época em que se dissolvessem as necessidades e expectativas do capitalismo e do comunismo estatal, permitindo que a natureza humana fosse reconstruída sob nova forma? É possível que eu esteja querendo demais. Seria invocar a possibilidade da redescoberta, sob novas formas, de um novo tipo de "consciência costumeira", quando mais uma vez as gerações sucessivas aprendessem umas com as outras; quando as satisfações materiais permanecessem estáveis (se distribuídas de modo mais igualitário), e só as satisfações culturais se ampliassem (THOMPSON, 2008, p. 24).

Antes mesmo desse escrito de I99I, Thompson já havia se pronunciado sobre sua aspiração de uma nova sociedade. Em um escrito de 1973, a Carta aberta a Leszek Kolakowski, incluída, posteriormente, em A miséria da teoria, Thompson enunciava a possibilidade de uma sociedade não pautada pela lógica do dinheiro e pelo espírito de cálculo. É instrutivo ler algumas linhas para perceber as ressonâncias do romantismo em sua escrita.

Minha própria utopia, duzentos anos à frente, não seria como a "época de descanso" de Morris. Seria um mundo (como diria D. H. Lawrence) onde os "valores do dinheiro" dariam lugar aos "valores da vida", ou (como diria Blake), a guerra "corpórea" daria lugar à guerra "mental". Com fontes de poder facilmente acessíveis, alguns homens e mulheres poderiam escolher 
viver em comunidades unificadas, localizadas, como monastérios cistercienses, em centros de grande beleza natural onde atividades agriculturais, industriais e intelectuais poderiam coexistir. Outros poderiam preferir a variedade e o ritmo da vida urbana, que redescobre algumas das qualidades da cidade-estado. Outros prefeririam uma vida de reclusão, e muitos passariam pelas três. Os acadêmicos acompanhariam as disputas de diferentes escolas, em Paris, Jakarta ou Bogotá. Mas fica-se desconfortável com tais sonhos. A imaginação utopiana, hoje, se desvia para o reino da ficção espacial, onde os autores examinam exatamente quais sociedades poderiam ser criadas se a consciência social se impusesse sobre o ser social. [...] Ser um utopiano em 1973 é ser considerado, na maioria dos círculos "respeitáveis", como um romântico e um tolo. Mas, talvez, cair em um "realismo" derivativo de uma obsessão com as más propensões do homem seja apenas o sintoma de um romantismo invertido ou depressivo. Pois perder a fé na razão do homem e em sua capacidade de agir como agente moral é desarmá-lo frente às "circunstâncias". E as circunstâncias, montadas sobre a má fé do homem, mais de uma vez nas últimas décadas pareceram inclinadas a matar-nos todos. [...] Neste momento histórico, nem o desespero nem o otimismo me parecem fundamentar-se em argumentos racionalmente atraentes. Resta ao homem agir e escolher (THOMPSON, 20I4, p. 99, IO0).

Como já mencionado, um dos últimos projetos de Thompson era a produção de uma obra sobre os poetas românticos da década de I790, mas a sua morte em 1993 deixou esse projeto inconcluso. A concretização viria, posteriormente, em duas etapas: a primeira com a publicação de Witness against the beast - William Blake and the moral law, editado ainda em 1993, e a segunda em 1997, quando Dorothy Thompson reuniu estudos menores de E. P. Thompson sobre os outros poetas ingleses na coletânea Os românticos - A Inglaterra na era revolucionária.

Dentre os estudos de Thompson sobre os poetas românticos, o que salta aos olhos é aquele sobre William Blake, tanto por sua extensão quanto por sua densidade. Todavia, Blake não aparece apenas nesse livro de Thompson, ele é uma figura importante já no livro de 1963, A formação da classe operária. Nessa "Londres jacobina" das últimas décadas do século XVIII, diria Thompson, Blake ascendeu como "a voz original e autêntica de uma longa tradição popular" (THOMPSON, 2004, p. 53). 
William Blake nasceu em I757, na cidade de Londres, e faleceu em I827. Era filho de um comerciante e desde muito jovem aprendeu a arte de compor gravuras para ilustrar livros. Blake também era um poeta e utilizou a arte da ilustração na edição de suas poesias, unindo o literário ao visual. Dentre suas muitas obras, é possível destacar $O$ casamento do céu e do inferno e Canções da inocência e da experiência.

Contra o espírito de cálculo, o mecanicismo, o racionalismo desmedido e tudo aquilo que anulava a imaginação, Blake encontrou refúgio na religião, no misticismo, não como uma via de escape e alienação, mas como uma forma de protesto ao vazio metafísico proveniente das Luzes. Blake encontrava no misticismo uma das formas de potencializar o próprio protesto social. Thompson, ainda na Formação da classe operária, já assinalava que era no interior do metodismo e nas diversas dissidências religiosas do século XVIII, com suas igrejas autogeridas e menos ortodoxas, que é possível encontrar "os germes do radicalismo político" (Ibidem, p. 23).

A relação de William Blake com a religião e o misticismo é uma dimensão que deve ser entendida no próprio quadro romântico de recusa do racionalismo, mas também à potencialização do religioso enquanto crítica social e política e, mesmo da religião, enquanto establishment. Thompson afirmava que, a última década do século XVIII e o início do século XIX, foram marcados por um surto milenarista, tanto naquilo que ele chama de "milenarismo autêntico", quanto no "milenarismo do desespero". O primeiro era capitaneado por Richard Brothers, que utilizava o Apocalipse para profetizar uma era revolucionária. Nesse espectro milenarista, Thompson também incluía William Blake. À segunda forma de milenarismo, Thompson relacionou, dentre tantas manifestações, a figura de Joanna Southcott, uma profetisa que conseguiu organizar uma dissidência do metodismo e arrebanhar cerca de Ioo mil pessoas. Ainda que tenha tido profunda admiração por Southcott, Thompson considerava que seu milenarismo não estimulava a ação revolucionária.

William Blake foi um crítico mordaz do metodismo, e isso é perceptível quando Thompson compõe a narrativa da herança espiritual de Blake. Ao fazer a genealogia de alguns valores caros à Blake, Thompson defrontou-se com as correntes religiosas radicais da revolução do século XVII. Segundo Michael Löwy, algumas dessas seitas pregavam “o amor em oposição à Lei Moral da Igreja e do Estado, e praticavam uma certa liberdade sexual e um tipo de comunismo primitivo". Para Thompson, se existia uma linha de continuidade nessa tradição rebelde, certamente a seita fundada por Ludowick Muggleton era uma das principais representantes, da qual Blake era um dos participantes. Isso explica 
a razão de Michael Löwy ter assinalado que "Thompson era fascinado pelos muggletonianos" (LÖWY, 20I4, p. 308).

Ao coletar as fontes muggletonianas para compreender suas ressonâncias na obra de Blake, Thompson não apenas se surpreendeu por essa seita estar ativa, um século após seu início, no tempo de Blake, mas também por encontrar o último, provavelmente, muggletoniano vivo, em 1975, um agricultor chamado Philip Noakes. Mr. Noakes não apenas conversou longamente com Thompson sobre a doutrina dos muggletonianos, mas também lhe deu acesso a cerca de 80 caixas de maçã onde eram mantidas as correspondências e publicações de quase 300 anos que documentavam a história da igreja (THOMPSON, I993, p. II7).

O objetivo de Thompson em Witness against the beast era mostrar como a obra de Blake foi marcada pela visão antinomiana dos muggletonianos. Assim, toda a primeira parte do livro é utilizada para historiar os principais movimentos antinomianos. Na segunda parte, Thompson cotejou a leitura de Blake com os documentos da seita e assinalou que a compreensão do poeta só era possível se se levasse em conta a cultura religiosa anti-hegemônica e antirracionalista da seita de Muggleton. Thompson argumentou que a tradição muggletoniana, temperada por Blake com o deísmo e o jacobismo, fez com que ele não tomasse o curso da apostasia, tal qual tomariam Wordsworth ou Coleridge (Ibidem, p. 229). Em outras palavras, Blake era um dissidente radical que conseguiu manter a fé, e essa era uma das razões de Thompson o admirar. Thompson, a seu modo, também foi um radical e dissidente, mas que também não tomou o caminho da apostasia política.

Sobre Witness against the beast, Michael Löwy fez duas observações cruciais no que diz respeito ao milenarismo e ao romantismo. Primeiro, o milenarismo, ou quiliasmo, como gostava de utilizar Thompson reportando-se ao grego, tão presente quando Thompson se referia a Blake na Formação da classe operária, praticamente desaparece em Witness against the beast. Segundo, o "mais espantoso ainda é a ausência, em Witness against the Beast, de qualquer referência ao romantismo de William Blake" (LÖWY, 20I4, p. 3IO).

A outra parte do projeto sobre os poetas românticos foi concretizada com o livro Os românticos - A Inglaterra na era revolucionária. Essa coletânea é composta de vários textos sobre Samuel Taylor Coleridge, William Wordsworth, William Godwin e John Thelwall. Ademais, a seleção é aberta com a transcrição da célebre palestra Educação e experiência, de 1968. Há ainda um posfácio, no qual Dorothy Thompson reuniu algumas palavras do marido sobre Mary Wollstonecraft. Para Thompson, o exame cuidadoso dessa autora, e de seu contexto, poderia abrir caminho para novas interpretações do início do romantismo e 
do efeito da contrarrevolução sobre as ideias de igualdade entre os sexos. Thompson advogava que, na década de I790, poderia ter havido "centenas ou milhares de pequenas Mary Wollstonecraft" que foram silenciadas ou reprimidas no período que se seguiu ao Terror. O título que Thompson proporia para esse escrito seria "A derrota dos direitos da mulher", e nele pretendia identificar "uma tradição esclarecida em certos setores da Igreja Não-Conformista - principalmente, entre os unitaristas e quakers", donde seria possível observar uma "aguda independência e inteligência - políticas, teológicas e intelectuais", frutos de uma "educação séria para moças" (THOMPSON, 2002, p. 299).

Em Os românticos, Thompson afirmava que no século XIX havia uma crise fundamental na cultura inglesa; apoiado em Raymond Willians, assegurava ter ocorrido uma crise entre "experiência e linguagem 'letradas' e 'populares'”. No entanto, asseverava que essa crise só podia ser entendida com a "eclosão da crise do romantismo dos fins do século XVIII", onde se observou, em praticamente toda a Europa, uma "cultura letrada ou refinada praticamente distanciada em relação à cultura da gente do povo" (THOMPSON, 2002, p. I4 e I5). No entanto, isso não significava um desprezo da aristocracia pela cultura do povo, visto que a estrutura paternalista ainda poderia ter assimilado vários poetas do povo com algum talento.

É na década de I790, quando as reivindicações por igualdade ganhavam a Europa, que a subordinação foi colocada em xeque. No centro dos acontecimentos ligados ao impacto da Revolução Francesa estavam Coleridge, Wordsworth, Godwin e Thelwall. Esses autores, cada um a seu modo, enfrentaram dificuldades pela simpatia ao jacobinismo. Os poetas Coleridge e Wordsworth eram "defensores indômitos da Revolução Francesa e ficaram enojados com o curso que ela tomou", não restando outra direção que não a apostasia e o desencanto. Coleridge tomou o caminho do conservadorismo e Wordsworth acabou por exilar-se na Alemanha, abandonando aos poucos a revolta romântica que impregnava seus poemas. Thompson assinalava que era tentador estabelecer paralelos entre o passado e presente:

[...] esse é um dos fascínios da época. E um dos seus perigos. Surgem as comparações fáceis, e estas se encontram subjacentes até mesmo quando ocultas. As revoluções Francesa e Russa; as Coalizões e a OTAN; a insurreição espanhola e a Hungria, I956; o godwinismo e o marxismo. [...] As grandes crenças políticas do humanismo levaram uma tremenda surra naqueles anos, e têm tomado outra surra no nosso próprio meio século (Ibidem, p. 56, 96). 
O jacobinismo inglês teve que conviver com o Terror do Comitê de Salvação Pública da França, as ações posteriores de Napoleão e a consequente contrarrevolução na Inglaterra. Para Thompson, essas experiências marcariam profundamente a sensibilidade dos poetas na Inglaterra, principalmente de Coleridge e Wordsworth, mas também de Godwin e Thelwall. O primeiro, como dito acima, alterou sua posição política ao reconciliar-se com o status quo e emprestar todo o seu prestígio de socialista utópico ao conservadorismo e à contrarrevolução. A situação do "bondoso Godwin" e de Thelwall, a "raposa jacobina”, também foi diretamente afetada pelos rumos da Revolução Francesa. O ano de I795 marcou a data da promulgação da lei dos Two Acts. Desde então, ficavam proibidas palestras políticas em associações ou mesmo agrupamentos em forma de assembleias. Isso atingiu em cheio Thelwall, orador inflamado e "o mais notório dos jacobinos públicos da Inglaterra”. Em suas palavras de recordação, em I8I9, assinalava como foi "proscrito e caçado - escorraçado como um animal selvagem, e banido como uma doença contagiosa" (THOMPSON, 2002, p. 63, 66).

O conjunto de textos e resenhas, reunidos postumamente em Os românticos, não tem uma conclusão. No entanto, é interessante observar as palavras finais de Thompson no texto Desencanto e apostasia para entender o que o autor pensava destes anos, que vão da última década do século XVIII até o fim das guerras napoleônicas. Seguem suas palavras:

Não consigo ver a década de I790, com sua fé excessivamente simples em fraternité e égalité, apenas como um museu para moralistas. [...] E penso frequentemente em Wordsworth, isolado em Goslar no inverno de 1799 "esse desperdício triste de esperanças destruídas", "quando os homens de bem/ tombam por toda parte, não sabemos como," opondo-se contra toda inclinação de debulhar o grão de humanismo na peneira. Sem a década de I790, não teria havido colheita a debulhar. Não é o local de descanso do apóstata que deve nos prender a atenção, mas o conflito ao longo do caminho, do qual surgiu a grande obra de arte. [...] Na nossa época, os homens se desencantam com facilidade demais, apressados demais em transpor a etapa da apostasia (Ibidem, p. 99).

As palavras de Thompson são sintomáticas. Elas não fazem apenas um juízo histórico sobre os poetas românticos da Inglaterra de I790, mas também devem ser lidas à luz dos acontecimentos da segunda metade do século XX. Os acontecimentos de 1956 
fizeram com que muitos intelectuais socialistas optassem pelo caminho do desencanto. No entanto, como se depreende, Thompson acreditava que era possível e necessário "transpor a etapa da apostasia" para salvar o humanismo.

Esses últimos textos de Thompson sobre os poetas românticos têm um caráter emotivo inegável, já que ele nunca negou as relações que estabelecia entre ativismo político, militância intelectual e escrita da história. Thompson "sempre conectou-se às suas opções historiográficas e sua defesa do socialismo, numa crítica contínua às violações da liberdades civis". A perspectiva política e teórica de Thompson sempre considerou "as noções de dissenso, protesto e resistência", o que levou o autor a conectar uma "história vista de baixo" a uma "política vista de baixo" (DUARTE, 2012, p. 343).

\section{Considerações finais}

Embora pouco evidenciada, exceção feita aos trabalhos de Michael Löwy, a tradição marxista tem uma relação estreita com o romantismo. Os próprios Marx e Engels tiveram suas obras marcadas pelo romantismo, não apenas pelo fato de terem vivido o "outono" da crítica romântica, mas por assimilarem algumas demandas dos autores românticos. As ciências sociais da Inglaterra, identificadas com o marxismo, também absorveram a crítica romântica ao capitalismo. Isso pode ser observado na história escrita por Eric Hobsbawm sobre os Rebeldes primitivos (1959), ou na análise de Richard Hoggart, em The uses of literacy (1957), sobre a destruição da cultura operária, ainda marcadamente camponesa, comunitária e afetiva, pela comunicação de massa e pelo ethos individualista e artificial. O mesmo pode ser dito das obras de Raymond Willians, Cultura e sociedade (1958) e A cidade e o campo (1973), onde o autor buscou traçar as linhas mestras da crítica romântica na Inglaterra, desde intelectuais conservadores até as relações do romantismo com o marxismo (LÖWY; SAYRE, I999).

E. P. Thompson, como pode ser visto acima, não estava imune a todo esse processo de recuperação do romantismo no seio do marxismo. Suas obras apresentam ressonâncias marcantes do romantismo, movimento que não apenas tomou como objeto de investigação, mas que admitiu como elemento epistemológico importante nas suas análises. Para Thompson, assim como para Morris, perscrutar a história, os antigos modos de vida, a relação dos camponeses com a terra, a comunidade, o tempo e a carestia, não era

\footnotetext{
${ }^{6}$ Essa dimensão da vida de Thompson também pode ser observada em seu ativismo político, principalmente na Campanha pelo Desarmamento Nuclear, na qual reconhecia a existência de um "humanismo rebelde". Ver (MÜLLER; DUARTE, 20I2).
} 
apenas um exercício diletante, mas uma forma de tomar um distanciamento intelectual do presente para melhor indagá-lo.

A história produzida por E. P. Thompson, filha de seu tempo, é melhor compreendida a partir de sua própria trajetória, de suas escolhas teóricas e políticas e de suas tomadas de posição. Ao restituir William Morris à tradição socialista, Thompson advogava pela imaginação utópica quase esmorecida em seu tempo, mas também defendia, contra as interpretações reducionistas da história intelectual inglesa, a existência de uma tradição rebelde, que vai desde poetas como Coleridge, Wordsworth, Godwin e Thelwall, passando por Mary Wollstonecraft, até chegar a William Blake. Ao buscar compreender o desencanto e a apostasia dos poetas ingleses frente aos ideais da Revolução Francesa, Thompson também tinha a sua frente os inúmeros casos de dissidência pós-1956.

A título de conclusão, há duas dimensões da relação de Thompson com o romantismo. Primeiro, a predileção do autor pelo romantismo é evidente quando ele historiciza essa própria sensibilidade artística nos poetas ingleses, e não é fortuito que sua vida tenha sido marcada, do início ao fim, pela leitura dos poetas românticos, que tenha iniciado sua obra biografando William Morris e terminado com um livro sobre William Blake, mantendo uma linha de continuidade na relação com o romantismo. Segundo, em trabalhos como Costumes em comum e A formação da classe operária há ressonâncias latentes da imaginação romântica na escrita de E. P. Thompson, marcando uma importante incorporação em sua forma de escrever.

\section{Referências}

DE DECCA, Edgar Salvadori. E. P. Thompson: Tempo e lazer nas sociedades modernas. In: Bruhns, Heloisa Turini (Org.). Lazer e Ciências Sociais: diálogos pertinentes. São Paulo: Chronos, 2002.

DUARTE, Adriano. Lei e costume: o essencial de E. P. Thompson. In: MÜLLER, Ricardo G. e DUARTE, Adriano (orgs.). E. P. Thompson: política e paixão. Chapecó: Argos/Unochapecó, 2012.

GONZALEZ, Alejandro E. Política, teoría e historia: el William Morris de E. P. Thompson desde la sociología de los intelectuales. Empiria. Revista de Metodología de las Ciencias Sociales. No 13.2007.

GREENBLATT, Stephen. O novo historicismo: ressonância e encantamento. Estudos Históricos. V.4, N.8. Rio de Janeiro: FGV, I99I. Disponível em: < http://bibliotecadigital.fgv.br/ojs/index.php/reh/article/view/2323> Acesso em: Io/o8/20I7. 
LÖWY, Michael. E. P. Thompson (I924-1993): a religião dos trabalhadores. História e Perspectivas. Uberlândia (I). jan./jun. 2014.

LÖWY, Michael; SAYRE, Robert. A corrente romântica nas ciências Sociais da Inglaterra: Edward P. Thompson e Raymond Willians. Revista Crítica Marxista. Campinas, nº 8, junho de 1999.

Revolta e Melancolia: o romantismo na contramão da modernidade. Petrópolis:

Vozes, 1995.

Romantismo e política. Rio de Janeiro: Paz e Terra, 1993.

MARX, Karl; ENGELS, Friedrich. Manifesto do Partido Comunista. Estudos Avançados. São

Paulo, V. I2, N. 34, I998. Disponível em:

<http://www.scielo.br/pdf/ea/vi2n34/vi2n34a02.pdf $>$ Acesso em 09/08/20I7.

MÜLLER, Ricardo G. (Org.); DUARTE, Adriano (Org.). E. P. Thompson: política e paixão. Chapecó: Argos/Unochapecó, 2012.

MÜLLER, Ricardo G.; MUNHOZ, S. J. Edward Palmer Thompson. In: LOPES, Marco Antonio (Org.); MUNHOZ, Sidnei (Org.). Historiadores do nosso tempo. São Paulo: Alameda, 2010.

PALMER, Bryan D. E. P. Thompson: Objeciones y oposiciones. Valencia: Universitat de Valencia Publicacions, 2004.

ROMANO, Roberto. Corpo e cristal: Marx e o romantismo. In: Corpo e Cristal: Marx Romântico. Rio de Janeiro: Ed. Guanabara, I98o.

Conservadorismo Romântico. Origem do totalitarismo. $2^{\mathrm{a}}$ ed. São Paulo: Ed.

UNESP, 1997 .

SALIBA, Elias Thomé. As utopias românticas. São Paulo: Brasiliense, I99I.

THOMPSON, Edward P. A miséria da teoria ou um planetário de erros. Uma crítica ao pensamento de Althusser. Rio de Janeiro: Zahar, I98I. (I ${ }^{\text {a }}$ ed. inglesa 1978).

William Morris, de romántico a revolucionario. Valencia: Edicions Alfons El Magnànim, 1988. (Iª ed. inglesa 1955).

- Witness Against the Beast: William Blake and the Moral Law. Cambridge: Cambridge University Press, 1993.

. Senhores e Caçadores. Rio de Janeiro: Paz e Terra, 1997. (Iª ed. inglesa 1975). . As peculiaridades dos ingleses e outros artigos. 3. ed. Campinas: Unicamp, 1998. Os românticos: a Inglaterra na era revolucionária. Rio de Janeiro: Civilização Brasileira, 2002. ( ${ }^{\mathrm{a}}$ ed. inglesa 1997$)$.

- A formação da classe operária inglesa: a árvore da liberdade. 3. ed. Rio de Janeiro: Paz e Terra, 2004. (I ${ }^{\mathrm{a}}$ ed. inglesa 1963). 
Costumes em comum. Estudos sobre a cultura popular tradicional. São Paulo: Companhia das Letras, 2008. ( $\mathrm{I}^{\mathrm{a}}$ ed. inglesa I99I).

. Carta aberta a Lezsek Kolakowski. Florianópolis: mimeo. UFSC. 20I4. ( $\mathrm{I}^{\mathrm{a}}$ ed. inglesa 1973).

THOMPSON, Dorothy. Prefácio. In: Os românticos: a Inglaterra na era revolucionária. Rio de Janeiro: Civilização Brasileira, 2002.

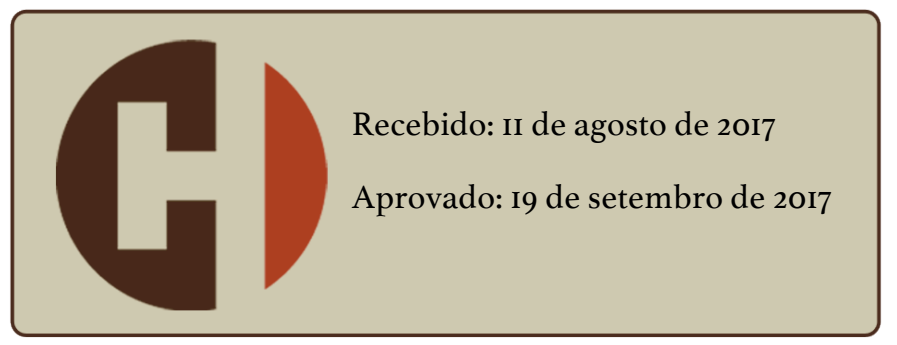

